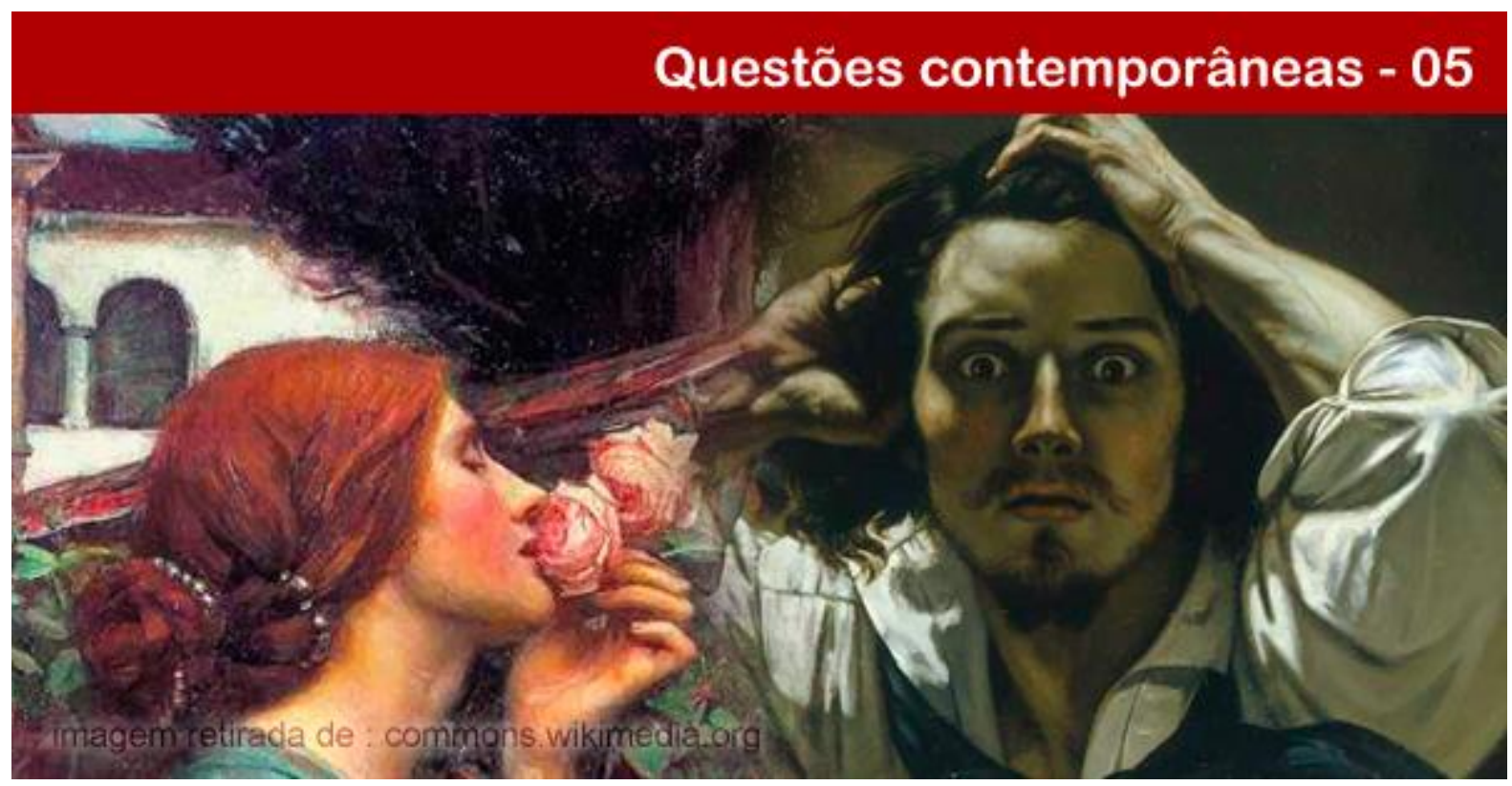

\title{
ESTRANHAMENTO E SENSORIALIDADE NA EXPERIÊNCIA DA PSICANÁLISE
}

\section{Morgana Rech}

Psicóloga clínica. Doutoranda em Teoria Psicanalítica pela Universidade Federal do Rio de Janeiro (UFRJ). Mestre em Teoria da Literatura pela Universidade do Porto. E-mail: mo.rech@ gmail.com.

\section{Estevan de Negreiros Ketzer \\ Psicólogo clínico. Doutor em Letras pela Pontifícia Universidade Católica (PUC/RS). E-mail: estevanketzer@gmail.com.}

Resumo: O artigo aborda o tema da experiência estética em sua relação com a clínica psicanalítica. Será analisado o papel do estranhamento, a partir das considerações de Sigmund Freud, para apresentar alcances teóricos novos à experiência estética. As noções de estética, em Freud, estão em diálogo com o trabalho de Loureiro, ao centrar a discussão até o momento cujo pensamento do estranhamento aparece como ponto fundamental da Síndrome de Stendhal. A partir deste ponto, há um desdobramento a ser incorporado pela clínica contemporânea, através de conceito de saída de si, por Gagnebin, e o conceito de saisissement, por M'Uzan. O artigo chega, então, até as discussões do dramaturgo Antonin Artaud com sua experiência do teatro da crueldade, ao reinterpretar a noção da obra de arte anterior ao domínio da palavra.

Palavras-chave: Estranho. Saisissement. Estética. Experiência.

\section{STRANGENESS AND SENSORIALITY IN THE PSYCHOANALYSIS' EXPERIENCE}

Abstract: The article addresses the theme of aesthetic experience in its relationship with psychoanalytic clinic. It will be analyzed the role of estrangement from the considerations of Sigmund Freud to present new theoretical approaches to the aesthetic experience. The aesthetics notions, in Freud, are in dialogue with the work of Loureiro, by focusing the discussion until the moment whose thought of estrangement appears as the fundamental point of the Stendhal Syndrome. From this point, there is an unfolding to be incorporated by the contemporary clinic through Gagnebin's concept of self-exiting, and the concept of saisissement, by M'Uzan. The article reaches then the discussions of the playwright Antonin Artaud with his experience of the theater of cruelty, while reinterpreting the notion of the work of art prior to the domain of the word.

Keywords: Strange. Saisissement. Aesthetics. Experience.

\section{POLÊM!CA $\mid$ LABORE (}

Polêmica - Revista Eletrônica da Uerj - Rua São Francisco Xavier, 524, $1^{\circ}$ andar bloco D, sl.1001 • Tels.: +55 21 2334-4088/4087 • http://www.e-publicacoes.uerj.br/index.php/polemica/index http://www.labore.uerj.br • laboreuerj@yahoo.com.br 


\section{Introdução}

Quais são as condições para a sensibilização do sujeito em psicanálise? Há uma interação do sujeito com seus afetos mais profundos que o aproxima de uma experiência estética. A compreensão da experiência estética no campo psicanalítico abrange questões e desdobramentos carregados de incerteza. Um primeiro motivo é a própria concepção que se tem desta experiência, bem como de suas possibilidades e impossibilidades de diálogo com outros campos do saber, tendo em vista a amplitude do assunto. Como adentrar-se na questão da experiência sem cair em devaneios vazios? Ainda assim, pode-se dizer que a questão da experiência estética e sua fruição vêm ocupando espaço nas discussões atuais sobre o lugar do corpo e, consequentemente, sobre as fronteiras com o psíquico, sendo útil para pensar variados fenômenos, em especial, o da relação do sujeito com a arte.

Levados estes aspectos em consideração, o presente trabalho tem por objetivo analisar o papel que a questão do estranhamento desempenha no pensamento freudiano, no sentido de sua influência para novos entendimentos sobre a experiência estética em sua dimensão sensorial. Para isso, será apresentada uma breve apresentação sobre as noções de estética em Freud, em diálogo com Loureiro (2003), centrando a discussão para o momento em que o estranhamento aparece como ponto fundamental em O Estranho, de 1919 (FREUD, 2006g). Neste processo, serão indicados desdobramentos atuais da questão, especialmente, através de conceitos utilizados por M'Uzan e Gagnebin. Finalmente, o trabalho discute a experiência do dramaturgo Antonin Artaud com sua experiência do Teatro da Crueldade, ao por em diálogo a noção da obra de arte anterior ao domínio da palavra.

\section{Questões gerais sobre estética em Freud}

Em diversos momentos de sua obra, Freud demonstrou interesse pelo tema da estética, afirmando a sua importância para a compreensão dos processos inconscientes e da relação humana com as produções artísticas. Como se pode ver em textos bastante iniciais, como: $O s$ chistes e sua relação com o inconsciente (2006a); Delírios e sonhos na Gradiva de Jensen (2006b); e Escritores criativos e devaneios (2006c). De uma maneira bastante experimental, a estética é convocada para estudar a particularidade da relação do sujeito com o objeto enigmático, seja este um chiste, uma obra artística ou uma construção onírica. São textos nos quais estas produções aparecem com o estatuto de auxiliares às necessidades vitais ou

\section{POLÊM!CA $\mid$ LABORË}


"sérias", como afirma Freud, em que "nada solicitamos ao objeto (...) contentando-nos, antes, com o prazer de contemplá-las" (FREUD, 2006a, p. 18). No caso dos chistes, por exemplo, o autor chega a essa conclusão a partir da observação do efeito causado no psiquismo por certos jogos de palavras que carecem de entendimento lógico nos códigos formais da linguagem, estando associado ao prazer desinteressado, com um fim em si mesmo. Freud afirma que "a atitude estética é lúdica" (FREUD, 2006a, p. 18), capaz de abrigar ideias aparentemente contrárias, contraditórias ou que simplesmente não possuem um sentido imediato.

O prazer envolvido nesse processo não seria dependente do conteúdo do chiste, mas da sua forma; tal prazer é entendido por Freud como estético ou de fruição e teria como característica principal a capacidade de conciliar entre o emissor e o receptor do chiste a mesma sensação prazerosa. Ressaltando a questão formal, Freud afirma: "Os métodos técnicos do chiste que já descrevemos anteriormente - condensação, deslocamento, representação indireta, etc. - possuem assim o poder de evocar um sentimento de prazer no ouvinte" (FREUD, 2006a, p. 97).

Em seu trabalho sobre a Gradiva, tentando compreender os mecanismos específicos da formação onírica, Freud estabelece um paralelo entre a narrativa do sonho e a narrativa literária. Neste texto, a estética é novamente abordada como espaço privilegiado de comunicação sensorial entre autor e receptor. Freud está interessado, a partir de suas próprias impressões em relação à arte, em compreender a origem do seu efeito prazeroso no psiquismo, procurando nele indícios para a compreensão de prováveis processos inconscientes aí envolvidos.

Pouco tempo depois, o tema foi abordado novamente em Escritores criativos $e$ devaneios (FREUD, 2006c). De uma forma mais concisa, Freud esclarece mais decisivamente o que considera como relação fundamental entre a criação de natureza artística e a criação de natureza onírica. Ele o faz articulando estas produções com a atividade lúdica típica do brincar infantil. Uma produção artística teria uma finalidade substitutiva, ao expressar uma realidade objetiva através de uma irrealidade imaginativa, ou melhor: de expressar uma sensação de desprazer através de uma experiência de prazer. Freud volta a afirmar que, através deste processo, a forma estética teria a capacidade de produzir o mesmo efeito no observador. Ainda que a análise deste texto seja bastante reduzida à relação da criação artística com o brincar infantil, Freud levanta questionamentos relacionados à forma e ao

\section{POLÊM!CA $\mid$ LABORE}


gênero da obra escrita, afirmando que "muitas obras imaginativas guardam boa distância do modelo do devaneio ingênuo" (FREUD, 2006c, p. 57). Contudo, assim como em outros pormenores ligados às especificidades da forma, Freud não desenvolveu esta questão, apenas indicando que mesmo nesses casos, como é exemplo o romance psicológico ou as re-criações de outras obras, é possível estabelecer uma explicação de teor transicional: a transposição de um desejo inconsciente na obra. No primeiro caso, conclui que o autor pode investir em um personagem como se fosse ele próprio. No segundo caso, dispõe de autonomia suficiente para escolher o material da sua própria obra (FREUD, 2006c).

Como afirma Loureiro (2003), até esse momento da teoria freudiana, a estética ainda não está definitivamente inscrita na ordem das necessidades, mas, conforme foi possível verificar nos textos citados, na ordem do lúdico e da fantasia, por indicarem a tendência inconsciente de realização de um desejo: "Mantém-se, pois, a ideia de que a atividade estética carece de utilidade imediata, embora não seja desprovida de intenção" (LOUREIRO, 2003, p. 29).

Já em 1913, em $O$ interesse científico da psicanálise ${ }^{1}$, a estética aparece em uma parte do texto dedicada ao interesse da psicanálise para as ciências não psicológicas e, embora ainda cercada de incerteza, parece tomar um contorno mais próximo da ideia de reação ao conteúdo inconsciente, sentido como estranho ou estrangeiro. Freud fala em apaziguamento de desejos não gratificados, tanto do artista como do espectador, questão que sugere uma separação mais delineada entre expressão e apreensão artística, assim como entre ação e reação ou de passividade e atividade. Para além de simplesmente compartilhar um espaço de fruição de sensações prazerosas, a estética aparece como meio de passagem a uma situação de atividade psíquica: "O objetivo primário do artista é libertar-se e, através da comunicação de sua obra a outras pessoas que sofram dos mesmos desejos sofreados, oferecer-lhes a mesma libertação" (FREUD, 2006e, p. 189). A arte seria, neste novo contexto, um modo especial de transformação de fantasias através de um código específico de comunicação que teria uma

\footnotetext{
${ }^{1}$ A título de observação, em uma análise sobre as várias noções de estética em Freud, Loureiro (2003) chama atenção para um equívoco terminológico: "Apesar das traduções sistematicamente traduzirem este item como "O interesse da psicanálise para a estética" ou "do ponto de vista estético", o título alemão é Das kunst wissenschaftliche Interesse - o interesse do ponto de vista de uma ciência da arte" (LOUREIRO, 2003, p. 27). Para a autora, tal equívoco é exemplo da transposição conceitual que se faz sobre as teorias freudianas sobre estética e arte.
}

\section{POLÊM!CA | LABORE}

Polêmica - Revista Eletrônica da Uerj - Rua São Francisco Xavier, 524, $1^{\circ}$ andar

bloco D, sl.1001 • Tels.: +55 21 2334-4088/4087 • http://www.e-publicacoes.uerj.br/index.php/polemica/index

http://www.labore.uerj.br • laboreuerj@yahoo.com.br 
capacidade singular, através das leis da belez $a^{2}$, de unir o inconsciente do sujeito que cria ao inconsciente do sujeito que observa, onde o não sabido já faz parte da obra (WILLEMART, 2009, p. 33). A estética revela aqui o quanto o estranhamento depende do contato com esse ‘ainda não' e o quanto a narrativa o comporta de modos muitas vezes pouco simplificados, deixando por vezes seus sinais criptografados.

Tendo como origem um conteúdo oculto à consciência, a arte constitui intermédio único de provocar emoções reais: "um meio-caminho entre uma realidade que frustra os desejos e o mundo de desejos realizados da imaginação - uma região em que, por assim dizer, os esforços de onipotência do homem primitivo ainda se acham em pleno vigor" (FREUD, 2006e, p. 189).

Em O Moisés de Michelangelo, Freud (2006f) questiona o papel do intelecto na afetação causada pela experiência estética, considerando que só depois de interpretada é que uma obra pode provocar uma emoção no observador, o qual, convém sublinhar, seria a mesma emoção que o artista imprimiu em seu trabalho criativo. Sobre este texto, Gagnebin (2009) comenta a importância que Freud dá, novamente, aos mesmos elementos que os do princípio do prazer, em sentido estético (linha, forma, contorno, etc.): "Freud parece levar em consideração os diferentes valores próprios a organizar a esfera da arte (...). Esses códigos de prazer sensual tomados na arte teriam, portanto, o efeito de aumentar a excitação" (GAGNEBIN, 2009, p. 182).

Essa ideia delimitaria a noção de estética como domínio das atividades associadas ao prazer obtido pelo próprio funcionamento do psiquismo e sem outra finalidade (LOUREIRO, 2003), designando um campo que diz respeito à beleza das obras humanas em geral, inclusive científica.

\section{A questão do estranhamento}

Uma nova perspectiva é introduzida a partir de 1919, com o texto $O$ Estranho. Neste trabalho, a questão é assumida como "teoria das qualidades dos sentimentos", como sublinha Loureiro (2003, p. 30). À medida que a estética já não se reduz, neste texto, ao prazer estético provocador de emoções tranquilizadoras ela assume características da categoria do belo. São

\footnotetext{
${ }^{2}$ Talvez esse seja um momento oportuno para assinalarmos que, conforme Loureiro, a teoria freudiana sobre a arte esteve subordinada à categoria do belo, pelo menos até as considerações feitas no texto $O$ Estranho, no qual a categoria do sublime parece estar em questão.
}

\section{POLÊM!CA $\mid$ LABORE}


sentimentos de natureza positiva, como resume Freud. Opostamente, por estranho ou "não familiar", o autor refere-se ao sentimento de inquietação que é experenciado diante do novo, incluindo as sensações de repulsa, aflição, medo e susto. Por estranho, Freud não quer dizer só o que é desconhecido ou novidade, já que nem todas essas experiências são assustadoras, mas do estranhamento ao qual "algo é acrescentado" (FREUD, 2006g, p. 239), indicando dessa forma uma ideia de retorno: "o estranho é aquela categoria do assustador que remete ao que é conhecido, de velho, e há muito familiar” (FREUD, 2006g, p. 238).

Freud parte de dois métodos de análise: a primeira, terminológica e linguística relacionada ao termo unheimliche (não-familiar); e outra a partir de "propriedades de pessoas, coisas, impressões sensórias, experiências e situações que despertam em nós o sentimento de estranheza" (FREUD, 2006g, p. 238), sendo a literatura uma especial fonte de exame. Os exemplos literários que Freud utiliza são extraídos de narrativas cujos recursos estilísticos são de teor fantástico, a partir dos quais constrói várias hipóteses, em diálogo com as ideias de Ernest Jentsch ${ }^{3}$. A primeira delas ${ }^{4}$ diria que o estranhamento se daria pela mera dubiedade dos elementos deste tipo de narrativa, que impõe ao leitor a imprecisão do limite entre estados de vida e morte ou, ainda do humano/não humano. A refutação vem logo e em seguida, ao passo que Freud verifica que nem todos os objetos que possuem tal aspecto causam o efeito de estranhamento, inclusive podendo ser geradores de outras emoções, como o prazer:

(...) sabemos agora que não devemos estar observando o produto da imaginação de
um louco, por trás da qual nós, com a superioridade das mentes racionais, estamos
aptos a detectar a sensata verdade; e, ainda assim, esse conhecimento não diminui
em nada a impressão da estranheza (FREUD, 2006g, p. 248).

Freud conclui que há algo a mais a ser levado em consideração, já que, a partir da análise dos elementos do conto O Homem de Areia, escrito por Ernst Theodor Amadeus Hoffmann, conclui que existem traços relativos ao conflito edípico, nomeadamente, o complexo da castração, participando do processo gerador do estranhamento. Desta forma, observa Freud, este algo mais seria a presença do recalcado, projetado para o exterior pelo ego como um mecanismo de defesa; por isso é sentido como estranho a si mesmo. Sobre este processo, Freud destaca o seu caráter de duplo: "há uma duplicação, divisão e intercâmbio do eu (self). E, finalmente, há o retorno constante da mesma coisa - a repetição dos mesmos

\footnotetext{
${ }^{3}$ On the Psychologyof the Uncanny, de 1906.

${ }^{4}$ Chamada de teoria da incerteza intelectual, por Jentsch.
}

\section{POLÊM!CA $\mid$ LABORE}


aspectos, ou características, ou vicissitudes, dos mesmos crimes, ou até dos mesmos nomes" (FREUD, 2006g, p. 252). É neste sentido que o estranho seria a presença de algo não arbitrário, com tendência à repetição e que veio à tona a partir da ligação inconsciente com outro elemento, o de seu duplo.

O fator da repetição da mesma coisa não apelará, talvez, para todos como fonte de uma sensação estranha. Daquilo que tenho observado, esse fenômeno, sujeito a determinadas condições e combinado a determinadas circunstâncias, provoca indubitavelmente uma sensação estranha, que, além do mais, evoca a sensação de desamparo experimentada em alguns estados oníricos (FREUD, 2006g, p. 254).

Sem demora, Freud refina a hipótese acima, considerando o fator da impossibilidade inconsciente experimentada pelos humanos de pensar sobre sua própria morte. Indica assim que toda essa dimensão de estranheza, provocadora de sensações inquietantes - ou, ainda, a imagem da casa assombrada - aponta para o primitivo pavor à morte, sempre pronto para se manifestar: "Considerando a nossa inalterada atitude em relação à morte, poderíamos, antes, perguntar o que aconteceu à repressão, que é a condição necessária de um sentimento primitivo que retorna em forma de algo estranho" (FREUD, 2006g, p. 259).

O estranhamento poderia estar presente, ainda, em uma série de outros contextos, como prevê Freud, no próprio efeito da psicanálise. Ela opera como "revelação de forças ocultas" - principalmente, no contexto da cura da histeria de conversão -, ou ainda, diante das práticas mágicas, nas quais estão sobrepostas a imaginação e a realidade, "aspecto estreitamente ligado à crença na onipotência dos pensamentos” (FREUD, 2006g, p. 291). A literatura, neste contexto, aparece como região intermediária entre o que seria uma investigação psicanalítica e uma investigação estética, fundamentalmente relevante para que Freud diferencie teoricamente aquilo que entende por experimentar o estranhamento ou imaginá-lo, indicando assim a diferença entre realidade material e realidade psíquica: “em primeiro lugar, muito daquilo que não é estranho em ficção sê-lo-ia se acontecesse na vida real; e, em segundo lugar, que existem muito mais meios de criar efeitos estranhos na ficção, do que na vida real" (FREUD, 2006g, p. 266).

Pela impossibilidade de submeter a ficção ao exame de realidade, a obra de arte funciona como prolongamento do fenômeno do estranho, oriunda de complexos que não se limitam a partes reprimidas do eu. Estranhamento que traz uma nova e renovadora noção sobre a partilha do sensível entre realidade e ficção: ambas unidas por uma camada invisível

\section{POLÊM!CA $\mid$ LABORE}


chamada consciência ou se preferirmos pura abstração racional. Ali onde o sentir não se deixa reduzir por uma linguagem geral, resumo concentrado na forma de um nome. "Que o inconsciente seja, num sentido lato, um fenômeno de significação, é evidente, mas é uma espécie de linguagem que perdeu ao mesmo tempo sua intenção de comunicação e sua intencionalidade referencial" (LAPLANCHE, 1988, p. 36). Para Laplanche o inconsciente justamente não é estruturado, pois, em sua abertura provoca, na ficção do impensável, reprimido ou impossível, a transformação de um nível de realidade interna ainda por vir. Ficção e realidade estariam tão imbricadas na nervura deste encontro por partilharem do estranhamento de uma vivência dissociada do $\mathrm{eu}^{5}$.

Em suma, o que está em jogo é que nem toda a ficção é capaz de provocar tal efeito, mas toda a sensação de estranhamento desta categoria é passível de ser colocada de forma ficcional, ampliando as suas possibilidades. Em todo o caso, ao final do texto, Freud sublinha o predomínio da passividade em que o sujeito se vê diante da sensação conflitante de ser tomado por algo que, embora não saiba o que é, está ostensivamente evidenciado pelo campo das sensações.

\section{Saisissement: a dimensão sensorial}

$\mathrm{Na}$ atualidade, alguns autores abordam a questão do estranhamento, alargando-o para discussões mais amplas que abrangem de forma mais efetiva a participação do campo somático na experiência estética. Nessas novas perspectivas, M’Uzan, Anzieu, Guillaumin, para citar alguns autores, a questão do estranhamento é examinando de forma acurada, articulando experiência artística e a experiência de análise.

Em diálogo com M’Uzan, Gagnebin (2009) retoma a ideia freudiana de inquietante estranheza (inquietante étrangeté), para enfatizar uma região de abertura no eu que mantém uma zona de intersecção entre as fronteiras do psíquico e do sensorial. Em tal região é que a experiência estética se revelaria, à medida que, concordando com Freud, caracteriza o território do estrangeiro, "ao lado do animismo, da magia, da onipotência dos pensamentos, das relações com a morte, das repetições involuntárias e do complexo de castração, o domínio da estética" (GAGNEBIN, 2009, p.185, tradução nossa).

\footnotetext{
${ }^{5}$ A intenção do comentário de Laplanche é chegar até o berço da experiência traumática, lugar cujos restos não permitem tradução por via de significantes, passando a ser esta a base da teoria das pulsões para o psicanalista (UCHITEL, 2011).
}

\section{POLÊM!CA $\mid$ LABORE}


Sua investigação parte de exemplos de estados alterados em função de experiências artísticas, nas quais ocorre uma profunda confusão ou excitação, como ocorre na chamada Síndrome de Stendhal, distúrbio que acomete turistas em visitação a Florença e outras cidades de arte. "No encontro do viajante com a obra de arte há sempre um 'invariante' - o deslocamento e o desenraizamento do entorno habitual, conhecido e familiar - e isto para ela é decisivo para o desencadeamento da síndrome, bem como para sua compreensão" (LOUREIRO, 2005, p. 106). Gagnebin sustenta que as obras de arte podem favorecer um choque similar ao momento de desequilíbrio econômico da libido presente nos momentos chaves da análise. No discurso analítico, uma revitalização econômica é provocada a partir da possibilidade de mudança de investimento de energia psíquica, afirma a autora. Este processo pode ser compreendido em termos de desvio e retorno aos limites do eu, caracterizando, assim, pequenos momentos de despersonalização, em que o sujeito experimenta o sentimento de saída de si. Cabe sublinhar que a autora não pretende comparar a experiência de análise com a experiência artística, mas afirmar o caráter de estranhamento presente numa e noutra esfera. Se o fenômeno é visto na sessão de análise, conclui, trata-se de um elemento permanente, um estado de abertura do ego, próprio ao aparelho psíquico. A inquietante estranheza, nesta visão, não se reduz à condição patológica, uma vez que se assemelha tanto ao retorno de um complexo infantil recalcado, como a um modo de defesa estruturante ou, ainda, como um déjà-vu (já visto ou já entendido). Por isso, consiste em uma espécie de manifestação diversificada do estranho, de acordo com Gagnebin (2009), em que a questão do duplo em Freud está sempre presente.

Estamos diante de uma esfera de sensações que de longe a consciência percebe facilmente. A experiência estética ruma em direção a uma nova formulação dessa experiência pela dupla analítica (analista e analisando) que se disponha a examiná-la. Seria, assim, um achado revolucionário o grito do poeta francês Antonin Artaud, por exemplo, o lugar da evasão do pensamento e a busca de um novo refúgio criativo gerado pelo sofrimento psíquico. "É por isso que uma imagem, uma alegoria, uma figura que mascare o que gostaria de revelar têm mais significação para o espírito do que as clarezas proporcionadas pela análise da palavra" (ARTAUD, 2006, p. 79). O poeta francês é considerado o inaugurador do happening (acontecimento) nas artes europeias, cujo sentido é despertar o que escapa à representação formal da palavra no plano simbólico. A questão aqui não é abolir o uso da palavra, mas

\section{POLÊM!CA $\mid$ LABORE}


mostrar que diante da estética algo excede os conteúdos declarados pelo som articulado ou estabelecido pela gramática. O jogo do estranho se entranha de tal forma capaz de iniciar um processo que a fenomenologia do simbólico pode, por vezes, se mostrar parcial ou mesmo artificial, se não estiver atrelada a uma conexão mais profunda com as intenções inconscientes mobilizadoras do encontro analítico pela perspectiva do analisando.

Seria este jogo objeto de interesse para a psicanálise? Não estaríamos entrando nele para nos perdermos? Se pudéssemos jogar mais luz sobre uma sensação do que sobre uma interpretação, talvez o som de Artaud tivesse um lugar no mundo. Sua poesia, pintura e dança expressas no teatro da crueldade tornam-se o receptáculo para esta pequena ruptura da representação conceitual envolvendo a vivência de uma sensação. Diante do pânico, do delírio, do deleite estético, da raiva, do sono e mesmo da lágrima: o corpo está antes da palavra. Talvez aqui fique mais clara a angústia de Artaud, de acordo com o relato de Anaïs Nin (1986, p.166): "Nada de palavras, nada de análise", exatamente onde o esquecido não chega à memória, o lugar da psicose e da pergunta perturbadora: "Você me acha louco?" (NIN, 1986, p.167). O constrangimento da escritora francesa é evidente. Estamos diante de um espaço cuja riqueza de sensações excede o nível formal daquilo que pode ser conceitualizado na clínica, merecendo ser pensando enquanto uma narrativa sui generis. A dupla vive junta esta cena da crueldade, crueza bruta do afeto e do jogo de fragmentos oníricos que ele desperta. Aprende-se a compartilhar. Ao vivenciar a emoção também se está a transformar a intimidade e toda uma gama de sentimentos tidos como trabalhados, no slogan do bem resolvidos, revoltos em diferentes tecidos de sensações. Contudo, a vivência das emoções no consultório traz um plano estético iminente e uma necessária conexão que está na base da manifestação estética da crueldade artaudiana:

\footnotetext{
O teatro só poderá voltar a ser ele mesmo, isto é, voltar a constituir um meio de ilusão verdadeira, se fornecer ao espectador verdadeiros precipitados de sonhos, em que seu gosto pelo crime, suas obsessões eróticas, sua selvageria, suas quimeras, seu sentido utópico da vida e das coisas, seu canibalismo mesmo, se expandam, num plano não suposto e ilusório, mas interior (ARTAUD, 2006, p.104).
}

Para o dramaturgo francês algo precisa voltar a circular, mas para tanto, é necessária uma nova conexão com esse interior. Assim como a expressão da arte clássica aprisionou o ser humano moderno em um jogo de representações cheias de palavras vazias, este mesmo

\section{POLÊM!CA $\mid$ LABORE}


gosto desenvolvido pela arte clássica impede agora o ser humano de valorizar outras emoções que o plano estético possibilita.

Um conceito mais recente assinala um desdobramento relevante destas questões em articulação com o papel da esfera sensorial nos processos mentais. Trata-se do conceito de saisissement, empregado por Michel de M'Uzan para designar o processo de estranhamento a nível corporal, característico especialmente na experiência artística: "um atirar-se ao infinito" (M'UZAN, 2010, p. 121, tradução nossa). Saisir, que indica a ideia de apreensão e captura estética, guarda também a ideia do duplo, ao passo que sugere um momento de passividade e atividade ocorrendo simultaneamente em três registros: afeto, percepção e pensamento (LOUREIRO, 2005).

A questão da compulsão à repetição, como já havia dito Freud em relação ao estranhamento, aparece neste contexto como fator elementar tanto da experiência de análise, como na experiência artística, nas quais há sempre um retorno a fazer. Segundo M'Uzan, tal compulsão define o viés de dependência presente na arte, chegando a colocá-la em paralelo às condutas adictas, no sentido do entorpecimento provocado e sempre reencontrado no encontro com a obra de arte. O fenômeno não se dá no quadro da relação objetal, mas de sua negatividade, de ser assombrado pelas suas exigências. $\mathrm{O}$ objeto, neste caso, cumpriria não uma função, mas um estado, cuja reabertura seria sempre convocada. Examinando especificamente a esfera da arte, o autor indica que nas experiências ditas estéticas, a partir da abertura ao nível sensorial, o sujeito é levado a um nível mais primário; aquém do registro psicossexual, no sentido da reabertura da própria problemática do narcisismo. Vê-se, dessa forma, a ênfase dada à dimensão somática, no sentido do ser orgânico de Inibição, Sintoma e Angústia (FREUD, 2006h), numa maneira de abordar a arte como um retorno ao ego corporal, uma forma de ir e voltar de si ou a imagem do corpo como uma esponja (M'UZAN, 2010, tradução nossa).

Para Gagnebin, o saisissement constitui apenas um dos elementos envolvidos na experiência estética, dentre outras questões que seriam tão importantes quanto esta. Neste momento, escreve a autora, sucede geralmente uma sequência de projeções e identificações nas quais as capacidades de ligação próprias ao $e u$ são então revisadas pelo sujeito que apreende. É a ideia de que a obra possui um corpo a ser internalizado pelo espectador, o corpo da obra (le corps de l'ouvre) na formulação de Anzieu: um prolongamento de sua própria

\section{POLÊM!CA $\mid$ LABORE}


dimensão corporal, que visa a reparação das suas carências autoeróticas ou, dito de outra forma, tende a restabelecer uma continuidade destas mesmas capacidades.

Assim como Gagnebin, outros autores como Didier Anzieu consideram importante descrever as várias etapas da experiência estética, indicando a ideia de saisissement como o momento inicial, de "transe corporal, angústia branca, estado quase alucinatório, de lucidez intelectual aguda. O sujeito registra o conteúdo sem necessariamente tê-lo provocado" (ANZIEU, 1981, p. 95, tradução nossa). A origem desse processo seria ou resultado de um trabalho preparatório ou realização de um desejo de criar até então negado. O processo estende-se a partir de uma representação única dotada de vivacidade, numa inundação de emoções, sensações e imagens, afirma Anzieu. Estas emoções, por sua vez, possuem as mesmas características de uma regressão e/ou uma dissociação, mais parcial e temporária do que um quadro regressivo ou dissociativo. Segundo Anzieu, "o saisissement criador é um momento psicótico não patológico" (ANZIEU, 1981, p. 105, tradução nossa).

É importante frisar que mesmo em casos de paranoia consagrados pela literatura psicanalítica a dissociação de estados afetivos do pensamento não significa prejuízo ou debilidade. Pelo contrário, no caso do Presidente Schreber, seus delírios são a possibilidade de contato com o mundo dos mortos, uma vez que "deus não compreende os homens vivos" (FREUD, citando Schreber, 2006d, p. 41). Com isso é mostrado que, mesmo em uma patologia severa como a paranoia, lida como estrutura psíquica do repúdio (Verwerfung), também encontra-se momentos de criatividade estética e riqueza elaborativa do que a ciência médica enxerga como pródromos da crise psicótica. Esta por sua vez toma uma forma mais misteriosa que o próprio Freud tenha pensado. A visão da psicanálise sobre a psicose é problemática, porém, gera muita discussão, pois está em mira que o desenvolvimento da amarragem da psicose a uma outra coisa que não a presença do falo paterno como desenvolvimento libidinal nos leva, impreterivelmente, a outras possibilidades que estão ligadas a outras significações de sentido que não envolvem a simbolização: "Um universal positivo próprio da psicose é extremamente problemático, porque, se não existe uma amarragem central para todos, seguramente nem podemos imaginar que exista uma significação que seja a mesma para todo sujeito psicótico" (CALLIGARIS, 1989, p. 33). O psicanalista ítalo-brasileiro está interessado neste trabalho que a investigação da psicose não

\section{POLÊM!CA $\mid$ LABORE}


cesse em um fundamento monista, mas se dirija aos diferentes modos pelos quais o desejo também se torna um deslocamento que ruma ao desconhecido que emana do inconsciente.

Dessa forma, novas perspectivas sobre a experiência estética indicam a importância do papel do sensório e do lugar do corpo, principalmente, no que diz respeito à elaboração psíquica e à reconstrução narcísica. Tais elaborações dizem respeito a uma perspectiva a ser debatida e indagada com mais profundidade pela comunidade psicanalítica, uma vez que envolvem a possibilidade de pensar conceitos em um campo de percepções estéticas. Aqui também há a importância da reestruturação do setting pela proximidade da intensidade do vivido junto ao outro. O corpo se mostra um espaço cheio de reentrâncias e dissonâncias produzidas e repetidas para alcançarem esse momento para além sui generis da criação.

\section{Considerações Finais}

Naturalmente, a experiência estética convoca mais de um movimento psíquico, abrangendo processos mentais complexos, impossíveis de abordar sem uma articulação com o papel do sensório e do lugar do corpo. A partir das considerações enfatizadas neste trabalho, foi possível verificar que em alguns textos iniciais freudianos a ideia de experiência estética designa um campo ligado ao lúdico, associado ao humor e ao brincar, indicando, por isso, a noção de fruição. Tal fruição possui natureza descompromissada e de satisfação substitutiva, estando inscrita na ordem do princípio do prazer. Em seguida, foi viável marcar a relevância da sensação de estranhamento para a compreensão da experiência estética. De acordo com Freud, existem objetos e situações capazes de provocar uma sensação que une prazer a desprazer, sentidos como estranhos ou estrangeiros. A conclusão do autor é que tal sensação se manifesta porque há a presença do recalcado, que coloca em jogo o retorno de complexos infantis e fantasias relativas à finitude da vida, através de um intermédio indefinido entre fantasia e realidade. Dentre estes objetos e situações, a ficção ocuparia um lugar favorecido por conceder uma gama maior de possibilidades de encontro com esse estranhamento cujo objetivo já não é apenas apaziguar, mas inquietar o sujeito.

O desdobramento deste campo teórico foi proposto a partir da ideia de inquietante estranheza, utilizado por diversos autores que buscam articular, na atualidade, discussões sobre o papel da esfera sensorial na constituição e dinâmica dos processos mentais, sendo a experiência estética uma importante fonte de investigação. A partir de algumas perspectivas

\section{POLÊM!CA $\mid$ LABORE}


apresentadas, como a de Gagnebin, em consonância com M’Uzan, indica-se que o campo da estética merece ser analisado tanto na relação do sujeito com a arte em sua experiência de análise: processos que, de formas distintas, pressupõem etapas específicas. A primeira delas seria o saisissement, fase inicial que compreende o instante de captura a nível sensorial dos objetos e situações causadores da inquietante estranheza, a partir da intervenção do outro. Isso quer dizer que, a partir do momento em que o lugar do corpo passa a ser convocado, o estranhamento adquire estatuto de operação fundamental do psiquismo, inquietante, pois sempre passível de reabertura, sugerindo um processo de efeito em diversas áreas dos processos mentais e corpóreos.

O grito de Artaud (2006) em seu Teatro da Crueldade faz uma ampla e irrestrita referência ao eu, enquanto um tensionamento de sua história e o esforço de fazer com que a estética também permita uma mudança a partir deste contato. $\mathrm{O}$ eu precisa reconhecer também uma vivência, diante da possibilidade eminente de sua própria ruptura, por exemplo, diante de um ataque às suas capacidades perceptivas, fato este que o saisissement não ficcionaliza, mas provoca o reconhecimento. $\mathrm{O}$ eu está aqui o tempo todo associado às mudanças que o permeiam, sejam internas ou externas: "Toda a obra de Freud atesta que em seu espírito, a noção de inconsciente é uma ideia histórica e evolutiva, sempre aberta às mudanças necessitadas pela experiência" (M’UZAN, 1977, p. 31, tradução nossa). Seria por demais negar que a teoria psicanalítica busca uma autenticidade, para além do enclausuramento em fórmulas, tanto edípicas quanto linguísticas. Aqui se abre "alguma coisa que porta sempre o nome do inconsciente" (M’UZAN, 1977, p. 32, tradução nossa), também afastando os filosofemas quando eles se mostram mais totalitários ou redutores diante da especificidade no encontro entre duas pessoas. Esta sensibilização não pode ser desprezada, sob o risco de toda a psicanálise esquecer-se do que está em jogo, diante da alteridade: a descoberta do outro sobre si mesmo.

Na percepção estética profunda somos invadidos por este encanto tão surpreendente como o olhar da criança ao construir seu arcabouço de palavras e sensações sobre as coisas que a cercam. Esse primeiro vislumbre de esperança utópica do acontecimento, unido à surpresa da hora mais vívida. Estranhamento, plasticidade, tradução e interrupção dos acontecimentos: saisissement no alento das horas que mostram esse estranho, estrangeiro, sua

\section{POLÊM!CA $\mid$ LABORE}


vinda por dentro de nós, como partes de outros ainda desconhecidos, à espera que lá a vida tenha sentido.

Afinal, seria este o plano artaudiano onde a palavra crueldade recebe seu deslocamento apreensivo sobre o corpo ao "romper de vez a armadura, arrebentar a golilha, voltar enfim às origens etimológicas da língua, através dos conceitos abstratos, evocam sempre uma noção concreta" (ARTAUD, 2006, p. 118). Tocar com lucidez este instante tremulante da loucura. O corpo que expele as partes mais desconectadas é o mesmo corpo que conecta os afetos. A descoberta desta psicossomática renova o horizonte da teoria. A confusão entusiasmada observada na Síndrome de Stendhal nos provoca o debate tenso entre os planos imanente e transcendente encontrados quando a sensibilidade do inconsciente invoca a criatividade da composição sempre inédita de um verdadeiro encontro.

\section{Referências}

ANZIEU, D. Le Corps de L'oeuvre. Éditions Gallimard, 1981.

ARTAUD, A. O teatro e o seu duplo. São Paulo: Martins Fontes, 2006.

CALLIGARIS, C. Introdução a uma clínica diferencial das psicoses. Artmed: Porto Alegre, 1989.

FREUD, S. (1905). Os chistes e sua relação com o inconsciente. In: . Edição Standard Brasileira das Obras Completas de Sigmund Freud. Rio de Janeiro: Imago, 2006a. v. 8.

(1907). Sonhos e Delírios na Gradiva de Jensen. In: Edição Standard Brasileira das Obras Completas de Sigmund Freud. Rio de Janeiro: Imago, 2006b. v. 9.

(1907). Escritores Criativos e Devaneios. In: Edição Standard Brasileira das Obras Completas de Sigmund Freud. Rio de Janeiro: Imago, 2006c. v. 9.

(1911) Notas psicanalíticas sobre um relato autobiográfico de um caso de paranoia (dementia paranoides). In: ___ Edição Standard Brasileira das Obras Completas de Sigmund Freud. Rio de Janeiro: Imago, 2006d. v. 12.

(1913). O Interesse Científico da Psicanálise. In:

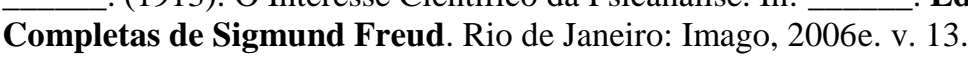
Edição Standard Brasileira das Obras (1914). O Moisés de Michelangelo. In: . Edição Standard Brasileira das Obras Psicológicas Completas de Sigmund Freud. Rio de Janeiro: Imago, 2006f. v. 13.

(1919). O Estranho. In: Edição Standard Brasileira das Obras Psicológicas Completas de Sigmund Freud. Rio de Janeiro: Imago, 2006g. v. 17.

(1926) Inibição, sintoma e angústia. In: Edição Standard Brasileira das Obras Psicológicas Completas de Sigmund Freud. Rio de Janeiro: Imago, 2006h. v.20.

\section{POLÊM!CA $\mid$ LABORE}


GAGNEBIN, M. L’inquiétante étrangeté en art. In: DANON-BOILEAU, L. Inquiétante étrangeté. Paris: Presses Universitaires de France, 2009. p. 179-202.

LAPLANCHE, J. Teoria da sedução generalizada e outros ensaios. Porto Alegre: Artes Médicas, 1988.

LOUREIRO, I. Notas sobre a fruição estética a partir de sua experiência-limite: a Síndrome de Stendhal. Psyche [online], São Paulo, vol.9, n.16, p. 97-114, 2005. ISSN 1415-1138.

Sobre as várias noções de estética em Freud. Pulsional: Revista de Psicanálise, São Paulo, ano XVI, n. 175, p. 23-32, nov. 2003.

M'UZAN, M. de. Créativité et addictions. In: CUPA, D. (et al.). Entre corps etpsyché: lesaddictions. Paris: EDK, 2010. p. 119-123.

De l'art à la mort. Paris: Gallimard, 1977.

NIN, A. Apêndice: um perfil de Artaud. In: ARTAUD, Antonin. Escritos de Antonin Artaud. Porto Alegre: L\&PM, 1986.

WILLEMART, P. Os processos de criação na escritura, na arte e na psicanálise. São Paulo: Perspectiva, 2009.

UCHITEL, M. Neurose Traumática. São Paulo: Casa do Psicólogo, 2011.

Recebido em: 03/02/2017.

Aceito em: 30/03/2017.

\section{POLÊM!CA $\mid$ LABORE}

